\title{
SOUVENIR BAGI WISATAWAN BALI
}

\author{
Oleh: \\ I Putu Gede Padma Sumardiana \\ padmasumardiana@gmail.com \\ UNHI Denpasar \\ Ni Luh Putu Trisdyani \\ trisdyani@uhni.ac.id \\ UNHI Denpasar
}

\begin{abstract}
ABSTRAK
Era globalisasi saat ini telah melahirkan industri baru yaitu berupa industri pariwisata yang telah menggeser nilai-nilai tradisional budaya agraris masyarakat menjadi sekedar hasil produksi berupa jasa dan barang. Dengan merebaknya industri pariwisata ini, oleh-oleh memiliki prospek tinggi dalam memberikan keuntungan berupa materi bagi masyarakat pariwisata dan menjadikan industri ini sebagai pendapatan terfavorit, karena kedatangan setiap wisatawan yang berkunjung ke sebuah tempat wisata, tentu menginginkan kenang-kenangan untuk dibawa ke Negara mereka masing-masing dan di sinilah peranan penting dari keberadaan souvenir sebagai salah satu komoditi pariwisata selain pertunjukan dan alam.
\end{abstract}

Kata kunci: Souvenir, Wisatawan, Bali

\section{ABSTRACT}

The current era of globalization has brought forth a new industry in the form of a tourism industry that has shifted the traditional values of the agrarian culture of society to merely the production of goods and services. With the outbreak of the tourism industry, souvenirs have a high prospect in providing material benefits for the tourism community and making this industry the most favorite income, because the arrival of every tourist visiting a tourist attraction, naturally wants a memento to be brought to their respective countries. -here and here is the important role of the existence of souvenirs as a tourism commodity besides performances and nature.

Keywords: Souvenir, Tourist, Bali

\section{PENDAHULUAN}

Dewasa ini pemerintah Indonesia memang secara massif mempromosikan berbagai daerah yang dianggap berpotensi menjadi tempat pariwisata. Tekad itu dijalin juga oleh semangat masyarakat yang mendukung perkembangan positif pariwisata baik dalam skup regional maupun internasional. Mengingat juga bahwa Pariwisata merupakan salah satu penghasil devisa andalan di negeri tercinta ini. Wacana yang telah ditetapkan tersebut telah berjalan dan berhasil membangun tingkat kesejahteraan masyarakat khususnya bidang ekonomi, sosial, budaya dan hankam. Banyak daerah bisa kita ambil 
sebagai contohnya, tak pelak juga adalah Bali.

Indonesia, termasuk Bali di dalamnya memiliki posisi yang sangat strategis dalam hilir-mudik jejaring pariwisata. Bagaimana tidak, keheterogenan budaya dan etnis yang menopang sekaligus menjadi umpan yang menggiurkan terlingkup di negeri ini. Kalo boleh kita sebutkan, mungkin tidak berlebihan apabila Indonesia dikatakan sebagai ensiklopedi etnis dunia. Dari sabang sampai merauke bisa kita kumpulkan beratus ragam etnik dan hal itu bisa kita sebut sebagai inventaris budaya yang tidak akan habis dieksplorasi.

Menukik lebih intensif ikhwal perkembangan budaya negeri ini, atau singkatnya budaya yang dielaborasi, terjabar berbagai perkembangan berikut pertumbuhannya yang dapat kita klasifikasikan sebagai rentang pertumbuhan yang "sehat" dan hal ini menjadi jaminan bahwa perkembangan dinamis kebudayaan kita akan terus berkesinambungan kearah yang lebih baik.

Kesenian dan budaya merupakan komoditas utama bagi industri pariwisata khususnya pulau Bali dan tanpa mengesampingkan keindahan alamnya. Bali, memang wacana yang menarik bagi wisatawan lokal maupun mancanegara. Sejak zaman penjajahan/kolonialisme bermigrasi menghantam, mendestruksi, merekonstruksi anatomi perdamaian di Bali, telah terbaca pula sebagian dari mereka menyadari bahwa pulau ini memang menyimpan misteri keindahan yang luar biasa. Sehingga pada proses selanjutnya, banyak dari mereka justru memilih untuk menetap dan bermukim, berbaur dengan masyarakat-penduduk Bali. Akulturasi budaya kembali berlangsung seiring perubahan umur terbentuknya dunia ini.
Memang sejauh catatan sejarah, terbentuknya Indonesia (baca: Bali) tidak terlepas dari peleburan berbagai ras dari berbagai belahan benua. Sistem perdagangan masa itulah yang disebut-sebut menjadi akar dan cikal bakal perkawinan silang budaya.

Menajuk pada influens berbagai budaya masa lampau, bisa kita tarik benang merah yang dapat membenarkan sekaligus menjadi bukti otentik perkawinan budaya tersebut. Bagaimana dengan keberadaan barong Ket di Bali yang kita sandingkan dengan barong Sae di daratan China, atau sedikit membaca lintasan hubungan nada antar etnis di nusantara ini. Bahkan bisa dibaca pula melalui visual art-yakni wilayah seni rupa; lukisan, patung, kriya dan art tefak yang banyak kita jumpai di museum purbakala.

Eksotis merupakan kata yang tepat untuk menyebutkan keindahan pulau Bali karena keunikannya. Pulau Bali memiliki berbagai kebudayaan maupun seni sebagai daya tarik pariwisata sampai saat ini. Selain memiliki kesenian dan budaya, Bali juga dianugrahi keindahan alam berupa pegunungan dan pantai, sesuai dengan Thank-Dam Truong dalam Soedarsono dikatakan bahwa ada lima $\mathrm{S}$ yang diperlukan dalam menggaet wisatawan manca negara untuk datang kesebuah daerah tujuan wisata. Kelima $\mathrm{S}$ yang dimaksud adalah: Sea (laut), Sand (pasir atau pantai yang berpasir), Sun (matahari), Sex (seks), dan Service (pelayanan) (Soedarsono, 1999:2) kesemua yang dipaparkan oleh Soedasono itu dimiliki oleh Bali sebagai komoditi pariwisata. Tetapi hanya satu $\mathrm{S}$ yang sangat tidak relevan digunakan sebagai komoditi pariwisata di Indonesia yaitu sex, dikarenakan norma- 
norma dan nilai-nilai ketimuran tidak membenarkan hal seperti itu.

Seperti yang dikatakan bahwah Bali memiliki potensi yang sangat baik dikarenakan keempat $\mathrm{S}$ yang dikualifikasikan kecuali sex oleh Soedarsono kesemuanya dimiliki Bali seperti yang penulis katakana di atas. Dan memang Bali merupakan salah satu tujuan utama pariwisata mancanegara datang ke Indonesia dan kini pariwisata telah menjadi industri terbesar di dunia, seperti menurut Dieter Braver, yang dikutip oleh Nyoman Sucipta : "tourism has become the biggest industry in the world. It offers jobs for 200 million people and contributes 11.7 percent to global Gross National Product. " (Sucipta, 2004:3). Bercermin dari pandangan Dieter Braver diatas, ternyata pariwisata memberikan hal positif terhatap kelangsungan hidup masyarakat khususnya di Bali untuk memperoleh pekerjaan di dunia industri pariwisata.

Bercermin dari tragedi memilukan sekaligus memalukan yang terjadi pada 12 Oktober 2002 hampir saja membunuh industri pariwisata ini. Ledakan bom yang meluluhlantakan Legian Kuta pada Jam 11 malam waktu setempat, telah merenggut banyak korban jiwa dari wisatawan mancanegara maupun pribumi. Tragedi ini telah membuat pariwisata di Bali mati suri, bagai pepatah mengatakan "hidup segan mati pun tak mau" dan juga membuat banyak terjadinya fenomena PHK pada kariawan-kariawan hotel maupun restoran. Kondisi ini semakain diperburuk oleh kejadian bom susulan setahun kemudian dan tempatnya masih di kisaran Kuta.

Terbersit dipikiran penulis mengenai kejadian maupun fenomena ini sebagai tamparan keras bagi kelangsungan industri pariwisata Bali dan mencoreng kesan Bali yaitu pulau yang aman dan nyaman. Kecolongan yang sampai lebih dari sekali ini menimbulkan pertanyaan penulis kepada aparat keamanan dalam kinerja menjalankan tugasnya untuk mengamankan industri wisata di pulau ini.

Saat ini kata syukur kehadapan Tuhan Yang Maha Esa sudah bisa kita ucapkan, karena pariwisata di Bali sudah bisa dikatakan bangkit kembali dari keterpurukannya yang disebabkan oleh ulah tangan manusia yang tak bertanggung jawab, sehingga banyak masyarakat kehilangan mata pencaharian khususnya di dunia industri pariwisata. Tetapi kejadian tersebut jangan dijadikan sebagai batu sandungan semata melainkan dijadikan sebagai refleksi bagi kita masyrakat yang hidup di "dalamnya".

\section{PEMBAHASAN}

Era globalisasi saat ini telah melahirkan industri baru yaitu berupa industri pariwisata yang telah menggeser nilai-nilai tradisional dalam artian budaya agrarisasi masyarakat saat ini. Sudah barang tentu dengan kata industri disini bisa kita tarik garis lurus yang berarti pariwisata harus menghasilkan suatu produk, jasa, dan juga sumber daya manusia yang nantinya dapat mendukung kepariwisataan disuatu daerah wisata.

Bali merupakan pulau yang memiliki potensi besar dalam menjalankan industri pariwisata tersebut, dikarenakan pulau yang memiliki banyak sebutan ini memiliki keunggulan geografi dan seni budaya sebagai komoditi yang sangat menguntungkan bagi kelangsungan maupun perkembangan industri pariwisata di Indonesia. I Wayan Ardika dalam buku "BALI MENUJU JAGADITHA: ANEKA PERSPEKTIF" mengatakan bahwa awal 
mula perkembangan pariwisata budaya yang nantinya menjadi cikalbakal indusri pariwisata di Bali ditandai dengan kedatangan sebuah perusahaan pelayaran Belanda yang telah mempromosikan pulau Dewata ini kepada pariwisata mancanegara pada tahun 1920an yaitu KMP (Koninklijk Paketvaart Maatschapij) (I Nyoman Darma Putra, 2003:20 ).

Tragedi pembantaian masyarakat Badung yang sekarang telah berubah nama menjadi Denpasar dan kita kenal sebagai tragedi Puputan Badung yang di lakukan oleh pemerintahaan Hindia Belanda, dan kejadian tersebut berdampak buruk bagi Negara tersebut. Mereka dikucilkan oleh Negara-Negara di Eropa dan mereka dianggap melakukan tindakan pengecut dikarenakan membantai lawan yang sudah tidak berdaya. Hal itulah yang melatarbelakangi pemerintahan Belanda mempromosikan Bali ke Warga Dunia "pariwisatanya" sebagai permohonan maaf juga pengakuan kembali oleh NegaraNegara Eropa.

Melihat dari latar belakang sejarah Bali yang cukup kelam sangat kontras penulis rasakan dengan perkembangan Bali saat ini khusunya dalam industri pariwisata, secara tidak langsung ucapan trimakasih bisa kita ucapkan kepada pemerintahan Belanda saat itu dan tidak bisa kita pungkiri bahwa peranan Belanda dalam mempromosikan Bali sebagai salah satu destinasi wisata kepada warga dunia dirasa sangat tepat. Seperti yang penulis katakana bahwa Bali memiliki potensi yang sangat besar untuk itu.

Seiring perkembanga industri pariwisata di Bali telah tercetus ide menggunakan daya tarik budaya lokal sebagai komoditi pariwisata. Penggunaan budaya disini sebagai komoditi sudah barang tentu meimiliki dampak positif maupun negatif pada masyarakat Bali khususnya. Seperti yang dikatakan Michel Picard dalam buku yang berjudul "BALI PARIWISATA BUDAYA DAN BUDAYA PARIWISATA" bahwa tradisi, seni dan agama, yang telah mengantar reputasi Bali di seantero dunia, merupakan daya tarik utama pulau itu dimata wisatawan, dan dengan demikianitu berarti menjadikan budaya sebagai "sumber" utama pembangunan ekonomi pulau. Namun, dilain pihak, mau tidak mau masuknya orang asing dalam jumlah yang besar dan dengan beraneka latar belakang budaya itu harus dipandang sebagai ancaman "polusi kebudayaan" (Michel Picard, 2006:187)

Terkait dengan pandangan diatas, penulis berpandangan bahwa penggunan budaya sebagai daya jual dari pariwisata di Bali secara langsung dapat membantu pengembangan pembangunan suatu wilayah yang dianggap memiliki prospek tinggi dalam pariwisata dan di sisi lainnya dapat menimbulkan polusi kebudayaan seperti yang penulis kutip dari kata-kata Picard. Penulis sendiri sependapat dengan pendapat yang di utarakan oleh Picard, kenapa demikian dikarenakan semakin banyaknya orang non Bali (asing) datang ke Pulau ini akan merubah mindset dari penduduk lokalnya, khususnya pada nilai budaya yang mereka miliki akan tergerus oleh budaya yang dibawa oleh wisatawan asing dari berbagai latar kehidupan. Contoh saja, saat ini banyak dari masyarakat Bali yang menganut seks bebas dikalangan anak muda dan sudah pasti budaya ini sangat tidak relefan dari latar budaya orang Indonesia maupun Bali, sehingga disini perlu peranan dari pemerintah untuk menanggulangi fenomena ini dalam menyelamatkan budaya 
Bali yang semakin terkikis oleh karat budaya luar.

Perihal ini harus mampu direduksi melalui strategi kebudayaan yang tepat. Ketahanan keberdayaan kebudayaan Bali yang besar dalam menghadapi berbagai pengaruh telah dikenal umum dan kebudayaan Bali mampu mempertahankan keunikan dan kekhasannya. Namun hubungan yang rumit dengan sistem nilai, struktur komunitas, sistem fisik dan agama Hindu.

Suatu strategi kebudayaan hakikatnya merupakan perangkat yang erat terkait dengan perangkat lainnya. Model rentangan visi, misi dan strategi merupakan satu model mata rantai kontinium yang sistematik bertumpu pada penalaran deduktif, dimana visi merupakan tujuan ideal (ideal goal), misi merupakan pendekatan dan proses ideal (ideal approach and process), sedangkan strategi adalah satu perangkat pendekatan dan proses yang praktis (pratical approach and process) (I Wayan Geriya, 2008:212). Menilik dari pandangan tersebut perlu adanya perencanaan-perencanaan yang matang guna memperkuat budaya yang sudah ada dan berkembang di Bali.

Berbicara mengenai otonomi daerah yang telah dicanangkan pemerintah terhadap Bali semenjak tahun 1998 memiliki dampak yang hampir sama seperti wacana pariwisata budaya tersebut yaitu dapat merubah "mindset" atau pemikiran masyrakat diberbagai plosok daerah untuk berlomba-lomba mempromosikan daerahnya sebagai tempat wisata, seperti yang dikhawatirkan oleh Pitana adalah pembangunan pariwisata Bali yang tidak terencana secara makro. Tentu dampak kedepan dari kekhawatiran Pitana sangat beralasan dikarenakan dampak otonomi daerah tersebut menimbukan rasa rivalitas persaing kabupaten atau kota dalam membangun daerahnya seluas-luasnya untuk menciptakan peluang PAD (pendapatan asli daerah dari pajak) (I Nyoman Darma Putra, 2003:xx). Bisa dikatakan awalnya akan berdampak baik terhadap pertumbuhan pembangunan pariwisata secara fisik, tetapi lambat laun akan menjadi bumerang yang mematikan bagi kelangsungan industri pariwisata di Bali dikarenakan adanya kejenuhan. Dampak lain dari otonomi daerah ialah secara tidak langsung akan membunuh budaya agraris yaitu pertanian dan akan mempengaruhi panorama alam Bali yang notabene merupakan daya tarik pariwisata.

Selain memiliki dampak buruk, tentunya otonomi daerah memiliki dampak positif bagi perkembangan industri pariwisata dewasa ini yaitu dapat menumbuhkan rasa persaingan positif terhadap kreator-kreator seni dalam mencipta suatu produk seni pariwisata berupa souvenir. Selain industri ini menjual seni pertunjukan dan keindahan alam sebagai daya tarik pariwisata dilain sisi perlu adanya pendamping dari kedua prihal tersebut yaitu barang lain berupa buah tangan bagi wisatawan.

Souvenir sendiri merupakan salah satu komoditi pariwisata berupa pernakpernik yang digunakan sebagai buah tangan bagi wisatawan yang berkunjung kesuatu tempat wisata. Menurut penulis dengan adanya souvenir sebagai buah tangan bagi wisatawan, secara tidak langsung para wisatawan akan selalu teringat pada tempat yang mereka kunjungi saat melakukan perjalanan wisata.

Terkait dengan souvenir, diresmikannya Desa Kamasan Bali sebagai kampung seni. yang launching pada hari 
Rabu (14/12/11), dikatakan oleh koordinator kampung BNI seni desa Kamasan, I Gede Eka Wedasmara. Ia mengatakan dengan diresmikannya Desa Kamasan sebagai kampung seni, pihaknya berharap kampung yang terkenal dengan seni lukisan khas Kamasan akan semakin dikenal dan akan banyak dikunjungi oleh wisatawan.

Karya seni yang berkembang saat ini masih diabadikan pada bangunan bersejarah Kertagosa yang berjarak kira-kira 40 Kilometer dari kota Denpasar. Selain lukisan Kamasan, salah satu souvenir khas di daerah itu adalah uang kepeng dan berbagai kerajinan dari perak dan emas.

Sama halnya dengan prihal yang dikatakana Picard, yaitu dibeberapa ruang pariwisata Pulau Bali harus disebut juga desa-desa pengerajin tertentu, sebenarnya telah menjadi tradisi bahwa masyarakat pedesaan di Bali mengkhususkan diri pada produksi-produksi kerajinan tertentu, misalnya pembuatan alat-alat musik atau menatah tempayan-tempayan perak, mengukir kayu atau batu, atau menyuling minyak kelapa dan tuak. Beberapa diantara desa pengerajin itu telah menyesuaikan diri pada pasaran pariwisata, sedangkan desadesa lainnya, tergiur oleh sukses desa lainnya, meniru dengan mengembangkan juga produksi kerajinan yang diarahkan ke pasaran wisata. Kini kerajinan pariwisata yaitu patung, lukisan, perhiasan, tenunan, anyaman dan lainnya adalah kegiatan khas Kabupaten Gianyar. Diantara desa-desa pengerajin itu, ada yang dikunjungi oleh para wisatawan selama turnya, dan ada juga yang berada di luar jalur wisata lalu mengirim produksinya ke resort-resort pariwisata atau ke obyek-obyek pariwisata di sekitarnya (Michel Picard, 2006:99-100).

Terkait prihal yang diungkapkan diatas, industri oleh-oleh memiliki prospek tinggi dalam memberikan keuntungan berupa materi bagi masyarakat pariwisata dan menjadikan industri ini sebagai pendapatan terfavorit, dikarenakan kedatangan setiap wisatawan yang berkunjung kesebuah tempat wisata, sudah barang tentu mereka menginginkan kenangkenangan untuk dibawa ke Negara mereka masing-masing dan disinilah peranan penting dari keberadaan souvenir sebagai salah satu komoditi pariwisata selain pertunjukan dan alam.

\section{PENUTUP}

Pada akhirnya, keberuntungan adalah usah dan kerja keras. Ketika kita mau berusaha, dengan sendirinya peluangpeluang akan bermunculan. Seperti keberadaan souvenir yang sangat penting sebagai ikon daerah sekaligus sebagai cinderamata bagi wisatawan.

Namun keberadaan souvenir itu haruslah diupayakan memiliki dan menjaga stabilitas kualitas yang berorientasi pada standar internasional. Apabila kita tidak bisa menjaga kualitas, secara automatisme memperburuk citra souvenir itu sendiri, dan menutup peluang yang lebih besar.

Tulisan ini sangatlah jauh dari kata "perfect" namun hanya berusaha respect. Kritikan dan saran yang membangun kearah positif sangatlah penulis butuhkan dari rekan-rekan dan dosen pengampu. 


\section{DAFTAR RUJUKAN}

Soedarsono. R.M. Seni Pertunjukan Indonesia \& Pariwisata. Yogyakarta. Masyarakat Seni Pertunjukan Indonesia. 1999

Darma Putra. I Nyoman. Bali Menuju Jagaditha: Aneka Perspektif. Denpasar. Pustaka Bali Post. 2004

Picard Michel. Terj: Jean Couteau, Warih Wisatsana dan Ade Pristie Wahyo. Bali Pariwisata Budaya Dan Budaya Pariwisata. Jakarta. Kepustakaan Populer Gramedia. 2006

Geriya. I Wayan. Tranformasi Kebudayaan Bali Memasuki Abad XXI. Surabaya. Paramita. 2008 